\title{
New and Renewable Energy Policies of Jeju Island in Korea
}

\author{
Youn Cheol Park ${ }^{1, *}$, Dong Seung Kim², Jong-Chul Huh ${ }^{1}$, Young Gil Kim \\ ${ }^{1}$ Department of Mechanical Engineering, Jeju National University, Jeju, Korea \\ ${ }^{2}$ Clean Energy Research Center, Jeju National University, Jeju, Korea \\ ${ }^{3}$ Future Strategic Industry Section, Jeju Special Self-Governing Province, Jeju, Korea \\ *Corresponding author. Tel: +82 647543626, Fax: +82 647563886, E-mail:ycpark@jejunu.ac.kr
}

\begin{abstract}
This study provides information on the energy status of Jeju Island in Korea (located at south of the Korean Peninsula), including general demographics, primary energy consumption and energy consumption by source, energy consumption by sector, power generation, and new and renewable energy.

The purpose of this study is to establish a regional sustainable energy supply system and to promote new and renewable energy industries throughout Jeju. Although Jeju, and Korea in general, already have some renewable energy development, there is strong demand and desire to greatly expand the level of renewable energy adoption. Jeju will not only expand the solar and wind industries, but also pursue bioenergy, geothermal power, hydropower, stationary and mobile fuel cells, ocean energy, and waste energy.

Jeju's regional energy planning is based on the Energy Basic Law established in 2006. Specifically, these programs have included policies supporting loans for purchase of renewable energy infrastructure, subsidies for renewable-based facilities, the 100 thousand green homes program, subsidies for solar thermal development, subsidies for local government investment in green technology, certificate programs, training programs, feed-intariffs, the formulation of new companies specialized in new and renewable energy, and regulations for mandatory use of new and renewable energy in new public buildings.
\end{abstract}

Keywords: Jeju Island, Renewable Energy, Energy Policy

\section{Introduction}

Energy use is a primary component of daily life. It is the basic to economic development and modernization. Energy consumption is also related to physical comfort and military strength. This fossil fuel-based lifestyle triggers some problems, such as economic instability, environmental pollution and hazards, and global warming. For economic instability, if the economic system of a country is based upon fossil fuels, the amount and price of fossil fuels, especially oil, will directly influence economic development and stability.

Regional energy planning is an extremely important component of any future development goal. Not only is it important for regions to know how development will unfold in their own jurisdiction, but also understand how development will unfold in nearby jurisdictions that are inherently linked to their own. Many times regional energy planning can capture specific development goals that are not achievable through national- or international-level policy. It is because of the localized framework in which regional energy plans are developed that they are able to focus on region-specific goals and accomplish tasks that are sometimes overlooked at the national level. In many areas of the world, regional energy plans have been under development for many decades and have become increasingly utilized since the 1990s.

The purpose of this study is to discuss the establishment of a regional sustainable energy supply system and to promote new and renewable energy industries throughout Jeju. Renewable energy development is an integral part of energy sustainability. Various forms of renewable energy can be exploited for electricity generation, with hydro and wind power currently dominating the renewable energy economy. Wind power is already competitive compared to fossil fuels in terms of cost of generation, and it has been shown that risk assessments favor this type of energy. 


\section{Basic Information}

\subsection{Overview of Energy Status in Jeju}

This section provides information on the energy status of the Province of Jeju, including general demographics, primary energy consumption and energy consumption by source, energy consumption by sector, power generation, and new and renewable energy as shown in Tables 1 to 6 . This information will be used at a later point in this paper to assist the analysis of the energy, environmental, economic, and social components of Jeju's energy framework.

Table 1. Area, population and gross regional domestic product (2006)

\begin{tabular}{ccccc}
\hline & $\begin{array}{c}\text { Area } \\
\left(\mathrm{km}^{2}\right)\end{array}$ & $\begin{array}{c}\text { Population } \\
(1,000)\end{array}$ & $\begin{array}{c}\text { Population Density } \\
\left.\text { (persons } / \mathrm{km}^{2}\right)\end{array}$ & $\begin{array}{c}\text { GRDP (2005, current } \\
\text { price, billion Won) }\end{array}$ \\
\hline Korea & 99,678 & 49,268 & 497.8 & $817,811.9$ \\
\hline Jeju & 1,848 & 560 & 303.9 & $7,663.9$ \\
\hline
\end{tabular}

Table 2. Primary energy consumption (2006) (Unit: 1,000TOE(Tonnage of equivalent energy))

\begin{tabular}{cccrcccr}
\hline & Total & Coal & Petroleum & LNG & Hydro & Nuclear & Others \\
\hline Korea & 233,372 & 56,687 & 101,831 & 32,004 & 1,305 & 37,187 & 4,358 \\
\hline Jeju & 1,149 & - & 1,120 & - & - & - & 29 \\
\hline
\end{tabular}

Table 3. Total energy consumption by source (2006) (Unit: 1,000TOE)

\begin{tabular}{cccccccc}
\hline & Total & Coal & Petroleum & City gas & Electricity & Heat energy & Others \\
\hline $\begin{array}{c}\text { Korea } \\
(\%)\end{array}$ & \multirow{2}{*}{173,584} & $\begin{array}{c}22,660 \\
(13.1)\end{array}$ & $\begin{array}{c}97,037 \\
(55.9)\end{array}$ & $\begin{array}{c}18,379 \\
(10.6)\end{array}$ & $\begin{array}{c}29,990 \\
(17.3)\end{array}$ & $\begin{array}{c}1,425 \\
(0.8)\end{array}$ & $\begin{array}{c}4,092 \\
(2.4)\end{array}$ \\
\hline $\begin{array}{c}\text { Jeju } \\
(\%)\end{array}$ & \multirow{2}{*}{924} & 0 & $\begin{array}{c}653 \\
(70.7)\end{array}$ & $\begin{array}{c}3 \\
(0.3)\end{array}$ & $\begin{array}{c}249 \\
(27)\end{array}$ & 0 & $\begin{array}{c}19 \\
(2.0)\end{array}$ \\
\hline
\end{tabular}

Table 4. Energy consumption by sector in Jeju (Unit: 1,000 TOE)

\begin{tabular}{lccccccc}
\hline Criteria & Total & Coal & Petroleum & City Gas & Electricity & Heat energy & Others \\
\hline Total & 924 & 0 & 653 & 3 & 249 & 0 & 19 \\
\hline Industry & 209 & 0 & 130 & 0 & 78 & 0 & 2 \\
\hline Transportation & 359 & 0 & 359 & 0 & & 0 & \\
\hline $\begin{array}{l}\text { Residential/ } \\
\text { Commercial }\end{array}$ & 302 & 0 & 151 & 3 & 146 & 0 & 2 \\
\hline Public \& others & 54 & 0 & 14 & 0 & 25 & 0 & 15 \\
\hline
\end{tabular}

The purpose of Jeju's mid- and long-term Roadmap is to establish a regional sustainable energy supply system and to promote new and renewable energy industries throughout Jeju. Korea already has some experience with renewable energy; as of June 2008, 100 thousand homes have adopted solar power systems, accounting for almost $22 \mathrm{MW}$ of photovoltaic power and an additional 8.4 MW is planned for power generation. Solar thermal water heating systems have also been in use since the 1970s, but have experienced technical setbacks. Wind power has also experienced some development with 192 MW of wind power installed by 2007 in Korea.

Table 5. Power generation (2006)

\begin{tabular}{ccc}
\hline & Generation Facilities (MW) & Generation (MWh) \\
\hline Korea & 65,514 & $381,180,710$ \\
\hline Jeju & 631 & $2,073,144$ \\
\hline
\end{tabular}


Table 6. New \& renewable energy (2006)

\begin{tabular}{ccccc}
\hline & \multicolumn{2}{c}{ Korea } & \multicolumn{2}{c}{ Jeju } \\
\hline & Capacity & Production(TOE) & Capacity & Production(TOE) \\
\hline Total & - & $1,249,920$ & - & 16,012 \\
\hline Wind & $78,941 \mathrm{~kW}$ & 59,728 & $3,210 \mathrm{~kW}$ & 9,196 \\
\hline Solar Power & $22,322 \mathrm{~kW}$ & 7,756 & $427 \mathrm{~kW}$ & 296 \\
\hline Solar thermal & $24,314 \mathrm{~m}^{2}$ & 33,018 & $269 \mathrm{~m}^{2}$ & 770 \\
\hline Geothermal & $10,007 \mathrm{RT}$ & 6,208 & $70 \mathrm{RT}$ & 28 \\
\hline Total & - & 274,482 & - & 2,861 \\
\hline Bio & $141,597 \mathrm{t} / \mathrm{y}$ & 53,346 & - & -- \\
\hline Biofuel & $30 \mathrm{t} / \mathrm{h}$ & 77,390 & - & - \\
\hline Biogas & - & 143,746 & $4,133 \mathrm{t}(\mathrm{RDF})$ & $2,861(\mathrm{LFG}, \mathrm{RDF})$ \\
\hline Others & $270 \mathrm{~kW}$ & 1,670 & & - \\
\hline Fuel cells & & & &
\end{tabular}

\subsection{Energy Development at a National Level}

Much of Jeju's positive attitude towards renewable energy comes from the overall Korean desire to achieve sustainability. In Korea's 2008 National Energy Basic Plan, goals were set to achieve a 46 percent energy efficiency improvement for newly installed energy and nearly fivefold increase in new and renewable energy by 2030. It is planned to expand photovoltaic power by 44 times, from 80 to 3,504 MW; wind 37 times from 199 to 7,301 MW; bioenergy 19 times from 1,874 to $36,487 \mathrm{G}$ cal; and geothermal 51 times from 110 to 5,606 G cal. Further, there are plans to introduce a renewable portfolio standard (RPS) with mandatory obligation for public buildings, and a 1 Million Green Homes program supporting wind, ocean, and bioenergy sources of energy. Lastly, the plan seeks to increase investment in research and development (R\&D) for wind, fuel cells, and solar power.

Achieving Korea’s goals will require an investment of 111.5 trillion won (\$93.3 billion USD) by 2030. A large portion of this funding will go towards basic $R \& D$, including the development of specific technologies such as Si PV (Silicon based Potovolatics) by 2015, thin Si PV and CIGS(Copper-Indium-Gallium-Selenide based Potovoltaics) by 2015, and organic PV by 2020. For wind power, goals are to develop 2 MW by 2010 and 5 MW by 2016 with a strong emphasis on wind turbines in urban areas, deploying by 2010. Solar thermal goals are the most aggressive, vying for $10 \mathrm{~kW}$ of generation by 2012 and $200 \mathrm{~kW}$ by 2013 .

Specific policy initiatives include market- and private-driven plans such as a RPS by 2012 including new and renewable energy for public and private buildings; and a major increase in the role of local government. Further, Korea seeks a large increase in private investment through policies including removal of market barriers, an increase in flow of public information, development of new industrial codes, and development of human resources.

\section{Regional New and Renewable Energy Pane}

Jeju's regional energy planning is based on the Energy Basic Law established in 2006, which consists of: (1) energy demand projections; (2) measures to provide reliable energy supply; (3) the new and renewable energy plan; (4) measures relating to carbon emission reductions;

(5) district heating development; (6) development of new energy resources; and (7) other energy issues necessary for the region. Specifically, these programs have included policies 
supporting loans for purchase of renewable energy infrastructure, subsidies for renewablebased facilities, the 100 thousand green homes program, subsidies for solar thermal development, subsidies for local government investment in green technology, certificate programs, training programs, feed-in-tariffs, the formulation of new companies specialized in new and renewable energy, and regulations for mandatory use of new and renewable energy in new public buildings.

Although the development of the $10 \mathrm{MW}$ wind farm in Haengwon(located in Jeju Island) is a noteworthy accomplishment, the wind farm accounts for only 1 percent of Jeju's electricity demand. Another project, the Green Village Project, includes 57 households powered by PV electricity, producing 160 thousand $\mathrm{kWh} /$ year and accounting for 75 percent of the households' loads. Excess peak electricity is sold back to the grid, thus turning some profit for the homeowners in wind Green Village. However, these projects account for a very small portion of total energy consumption and thus renewable energy development is needed to a much greater degree.

The prospects for new and renewable energy development in Jeju are promising, since 60 percent of the national wind potential is concentrated in Jeju Island if its offshore areas are included. As such, Jeju plans to build 500 MW of wind generating facilities by 2020, accounting for 20 percent of Jeju's total electricity demand at that time. Jeju plans to achieve this level of growth by concentrating on self-generating facilities located close to the endusers and limiting the development of large-scale facilities. Jeju will also consider the development of transmission lines between the mainland and the island, allowing for transmission of excess generation or sale of generation at a competitive rate.

Geothermal development will face barriers of high cost, but is applicable for large-scale projects. Comprehensively, Jeju hopes that the 20 percent target for wind power can be achieved sooner than planned. In the meantime, Jeju will deploy large geothermal generation plants to complement the intermittency of wind and solar power. Landfill gas plants will also provide additional renewable energy. Hydrogen power is a longer-term prospect, but a hydrogen refueling station is already being considered at the site of the Haengwon wind farm for the purpose of introducing a hydrogen car by the end of 2009.

\subsection{Wind Power}

Jeju has outlined basic goals to foster increased wind power development in the province by maximizing its wind potential for future energy resources. In 2050 produce 440.8 thousand TOE (936.2 MW) potential energy by wind power, accounting for 30 percent of renewable energy supply.

Jeju's public and private investment projects for wind power seek to develop 936MW of wind capacity by 2050 according to the following schedule: 289MW in 2013, 565 MW in 2020, 809MW in 2030, and 936MW in 2050. Out of $809 \mathrm{MW}$ in 2030, $609 \mathrm{MW}$ is scheduled to come from the off-shore wind development. As of 2007 the installed wind capacity in Jeju was only 34MW. As of the end 2008, the installed capacity of wind power in all of South Korea was 236MW.

Jeju Island's first demonstration project for wind power generation was planned by the Korean Government's Ministry of Trade, Industry and Energy and the Korea Institute of Energy Research (KIER), and started operating in February 1995 (CADDET, 1998). In 2003 the first major wind farm was installed in the island. Local government administration has enjoyed broad autonomy while the public support for environmental conservation increases. 
For these reasons, Jeju has good prospects to develop renewable energy sources, including wind power.

Jeju has outlined goals to meet 30 percent of its renewable energy with wind power by 2050 . The above global trends in wind power development combined with Jeju's excellent wind potential suggest that Jeju could have more than 30 percent of renewable energy supply from wind power. According to the Roadmap, 60 percent of Korea's national wind potential is concentrated at Jeju Island including its offshore areas. This potential should be exploited to the furthest degree possible. In most applications, wind power is least expensive form of renewable energy and Jeju should pursue this technology as its flagship renewable technology.

\subsection{Geothermal Power}

Jeju has outlined basic goals to foster increased geothermal energy development in the province, especially through building geothermal facilities located close to the industrial sites. In 2050 produce 220.5 thousand TOE (130.1 MW) of energy by geothermal power, accounting for 15 percent of total renewable supply.

This project involves a trial development of geothermal electricity and heating and cooling services for large-scale industrial parks in Jeju. This project will involve the attraction of private capital as well as a feasibility study on a 10MW geothermal plant. The benefits of this project include the development of a true fossil fuel-free city which relies entirely on renewable energy. This will likely prove to have environmental and economic benefits for the businesses located in the industrial park.

In Korea, hydrogen fuel cells, PV, and wind power have been selected as the main areas of development (IEA, 2004). For geothermal energy, Korea has just begun to develop its geothermal resources, and the technology has not been implemented on a large scale. Compared with other countries it is evident that geothermal use in Korea is considerably less than other similar regions. As such, the government should devote greater resources to developing advanced geothermal resources, especially in geographically-promising areas like Jeju.

Geological conditions and economic costs are two crucial limitations for geothermal energy development. Jeju island has abundant geothermal potential and has annual investment plan from year 2008 to 2011. Therefore, geothermal energy could play a significant role in Jeju's renewable energy future.

\subsection{Solar Power}

Jeju has outlined basic goals to foster increased solar power development in the province. Solar power, especially PV, is currently being heavily researched both in academia and in the industrial sector. Solar power is a broad term that covers many different types of energy production. Among these are photovoltaics (PV) and different types of solar thermal such as solar hot water and large scale solar thermal power. Jeju could build solar power plants by using surplus property within wind farms. A summary of the goals, as discussed in Jeju's Roadmap, is provided here. In 2050 produce 110.1 thousand TOE (449.7 MW) of energy by solar PV power, accounting for 7.5 percent of total energy supply. In 2050 produce 36.8 thousand TOE (681,482 square meters) of energy by solar thermal power, accounting for 2.5 percent of renewable energy supply. 
By 2030, the target of Jeju's renewable resources in total will account for 30 percent of the energy supply. Since Jeju island has a high degree of solar insolation, it is projected that solar PV will account for 8 percent and concentrated solar thermal plants will account for 2 percent.

The use of solar power technologies in South Korea is becoming increasingly important to meet the growing needs of energy and address the shortage of energy resources. In addition, electricity generated through renewable energy sources has been aggressively promoted because energy prices are soaring and awareness of environmental issues is increasing. To facilitate more extensive adoption of solar power electric generation, Jeju launched programs and incentive policies aimed at increasing solar energy supply, such as direct funding of solar installations, the green home project, and the construction of the solar power plant. Further, Jeju will create a desalination plant using solar energy, which in effect advances both desalination and solar technologies.

\subsection{Biomass and Biofuels}

Jeju has outlined basic goals to foster increased biomass development in the province. $R \& D$ will be conducted to develop vehicle technology in order to accommodate biogas industry. By 2030, 25 percent of diesel consumption will be replaced with biodiesel (BD20 blend). In 2050 produce a total of 10 thousand TOE (9,479 net cubic meters) of energy by biogas. In 2050 produce a total of 136.9 thousand TOE (161,000 kiloliters) of energy by biofuels. In total, biomass will account for 10 percent of renewable energy supply.

The biofuel projects involve the construction of biodiesel production and supply facilities from 2007 to 2010 and secondly, bioethanol production and supply facilities from 2010 to 2012. The biodiesel(feedstock is Rapeseed Oil) project will have an installed production capacity of 3.4 million gallons (13,000 kiloliters) per year. The bioethanol project will have an installed capacity of 22.1 million gallons (76,000 kiloliters) per year and will produce and supply bioethanol by using discarded citrus for processing.

The biogas projects involve the creation of a biogas facility using livestock manure and other organic waste sources. The goals are to treat organic waste at a rate of $100 \mathrm{t} /$ day and produce biogas at $11,000 \mathrm{~m}^{3} /$ day and organic fertilizer at 20t/day. The project will have a total investment of US\$362 million (420 billion Won).

\subsection{Hydrogen and Fuel Cells}

Jeju has outlined basic goals to foster increased hydrogen development in the province. The goal is to provide a hydrogen economy through a focus on hydrogen technology. In 2050 produce 514.4 thousand TOE (455 MW) of energy by fuel cells, accounting for 35 percent of renewable energy supply.

This project involves the construction of a test and evaluation research center for hydrogen and fuel cells. Construction of the research center will have a total budget of US\$31.9 million (37 billion Won) (from the Central Government) and had been constructed from 2005-2008 by the Korea Institute of Energy Research. Secondly, the project involves a monitoring project for commercialization of the hydrogen fuel cell vehicle supply. The monitoring project will have a total budget of US\$82.8 million (96 billion Won) and will be undertaken from 2008-2010 by the Central Government and Hyundai Motors. This project will include the construction of two hydrogen stations and operation of four hydrogen-electric vehicles (three sedans and one bus). The primary benefit of this project is the development of an integrated system of fuel cells and hydrogen which is produced from domestic renewable energy resources. 
The hydrogen source in Jeju could be electrolysis. The electricity of the power needed to electrolysis is wind power. As mentioned before, Jeju has a large potential of the wind power even the electricity consumption of the province is small. The idea to using hydrogen in Jeju is based on surplus wind power which cannot be used due to quality of electricity when it connected to the grid line.

\subsection{Specific Development Targets}

The Korean central government aims to increase the share of new and renewable energy in electricity generation to 11 percent of total energy demand by 2030 (National Energy Basic Plan in 2008). In response to these goals, Jeju pursues the development of six leading new and renewable projects, including projects for wind, geothermal, solar, biodiesel, bioethanol, biogas, and hydrogen.

Mid- and long-term projections of electricity demand show an annual growth rate of 2.5 percent for Korea and 2.4 percent for Jeju to 2020. The annual growth rate of primary energy in Jeju will be 2.2 percent during 2007-2016; then 1.5 percent during 2017 to 2030; and then 0.7 percent during 2031-2050. Wind power generation will experience rapid growth, accounting for 9 percent of electricity demand in 2011, 17 percent in 2015, and 28 percent in 2020. Renewable energy in total will account for 10 percent in 2013, 20 percent in 2020, 30 percent in 2030, and 50 percent in 2050. By 2030, wind energy will account for 50 percent of total renewable generation, solar will account for 8 percent, concentrated solar thermal plants will account for 2 percent, geothermal 15 percent, bioenergy 10 percent, and fuel cells 15 percent as shown in Table 7.

Table 7. New and renewable energy supply targets by energy source(Unit: 1,000TOE)

\begin{tabular}{|c|c|c|c|c|c|}
\hline Year & 2007 & 2013 & 2020 & 2030 & 2050 \\
\hline \multirow{2}{*}{ Wind } & $16.0(90.4 \%)$ & $136.2(70 \%)$ & $266.4(60 \%)$ & $380.8(50 \%)$ & $440.8(30 \%)$ \\
\hline & $34 \mathrm{MW}$ & $289 \mathrm{MW}$ & $565.8 \mathrm{MW}$ & 808.8 MW & 936.2 MW \\
\hline \multirow{2}{*}{ Solar Power } & $0.34(1.9 \%)$ & $17.4(8.9 \%)$ & $56.6(12.7 \%)$ & $60.9(8.0 \%)$ & $110.1(7.5 \%)$ \\
\hline & $1.36 \mathrm{MW}$ & $71.1 \mathrm{MW}$ & 231.2 MW & 248.7 MW & 449.7 MW \\
\hline \multirow{2}{*}{ Solar thermal } & $0.046(0.2 \%)$ & $2.1(0.1 \%)$ & $10.0(2.3 \%)$ & $15.2(2.0 \%)$ & $36.8(2.5 \%)$ \\
\hline & $848 \mathrm{~m}^{2}$ & $38,889 \mathrm{~m}^{2}$ & $185,185 \mathrm{~m}^{2}$ & $281,482 \mathrm{~m}^{2}$ & $681,482 \mathrm{~m}^{2}$ \\
\hline \multirow{2}{*}{ Geothermal } & \multirow{2}{*}{0} & $7.7(4.0 \%)$ & $44.4(10 \%)$ & 114.3(15\%) & $220.5(15 \%)$ \\
\hline & & $4.5 \mathrm{MW}$ & $26.2 \mathrm{MW}$ & $67.4 \mathrm{MW}$ & 130.1 MW \\
\hline Bio energy & $1.3(7.3 \%)$ & $30.2(15.5 \%)$ & $44.4(10 \%)$ & 76.1(10\%) & $146.9(10 \%)$ \\
\hline \multirow{2}{*}{ Fuel cells } & \multirow{2}{*}{0} & $1.0(0.5 \%)$ & $22.2(5 \%)$ & $114.3(15 \%)$ & 514.4(35\%) \\
\hline & & $0.88 \mathrm{MW}$ & 19.6 MW & 101.1 MW & 455 MW \\
\hline Total & 17.7 & 194.6 & 444.0 & 761.7 & $1,469.5$ \\
\hline
\end{tabular}

\subsection{Annual Investment Plan('09-'13 $1^{\text {st }}$ step Project)}

The Annual Investment Plan for 2009 to 2013 is the first step in a larger scheme. The plan has a total budget of US\$718.8 million (833 billion Won). Details on the allocation of the budget are provided in Table 8. 
Table 8. Jeju's annual investment plan (Unit : Million Won)

\begin{tabular}{crrrrrrr}
\hline & \multicolumn{1}{c}{ Total } & \multicolumn{1}{c}{08} & \multicolumn{1}{c}{09} & \multicolumn{1}{c}{10} & \multicolumn{1}{c}{11} & \multicolumn{1}{c}{12} & \multicolumn{1}{c}{13} \\
\hline Total & 833,100 & 101,610 & 207,527 & 57,028 & 178,855 & 149,040 & 139,040 \\
\hline Central Government & 53,067 & 5,700 & 27,767 & 4,800 & 4,800 & 5,000 & 5,000 \\
\hline Jeju & 44,153 & 7,800 & 22,953 & 3,200 & 3,200 & 3,500 & 3,500 \\
\hline Private Investment & 627,255 & 30,500 & 143,820 & 41,000 & 160,855 & 130,540 & 120,540 \\
\hline Research Institute & 108,625 & 57,610 & 12,987 & 8,028 & 10,000 & 10,000 & 10,000 \\
\hline
\end{tabular}

\section{Conclusions}

The Roadmap has clearly identified the energy demand and supply up to the target year (2050). The target year of choice is an important component of the regional energy plan. The Roadmap's proposed rates of the development of new and renewable energy sources correlate to each decade and are interestingly proportional as shown in Table 9. Jeju aims for 20 percent new and renewable energy share in 2020; 30 percent in 2030; and 50 percent in 2050. Achieving a 50 percent renewable energy contribution will require aggressive and smartlycrafted policy intervention.

Table 9. Overview of new and renewable energy supply targets in Jeju(Unit : 1,000TOE)

\begin{tabular}{cccccc}
\hline & 2007 & 2013 & 2020 & 2030 & 2050 \\
\hline Primary energy demand & 1,708 & 1,946 & 2,220 & 2,539 & 2,939 \\
\hline Renewable energy & 17.7 & 194.6 & 444.0 & 761.7 & $1,469.5$ \\
\hline Renewable share (\%) & $1 \%$ & $10 \%$ & $20 \%$ & $30 \%$ & $50 \%$ \\
\hline
\end{tabular}

\section{References}

[1] CADDET, Wind power generation at Jeju island, Korea. 2009

[2] IPCC, Climate Change 2007: The Physical Science Basis, Contribution of Working Group I to the Fourth Assessment Report of the Intergovernmental Panel on Climate Change, Summary for Policymakers, 2009.

[3] IEA, Energy Efficiency; Policies and Measures. Retrieved November 20, 2009.

[4] Korea Energy Economic Institute, Economic Analysis in Renewable Energy, 2008.

[5] EWEA, Global 2008 Wind Energy Statistics, 2009. 